\title{
Review
}

\section{Thought in the act: Passages in the ecology of experience}

\author{
Erin Manning and Brian Massumi \\ University of Minnesota Press, Mineappolis and London, 2014, ix+187pp., ISBN: \\ 978-0816679676
}

Contemporary Political Theory (2015) 14, e22-e24. doi:10.1057/cpt.2014.62;

published online 20 January 2015

This book feels very timely. After a thrust of writing in political theory looking at embodied practices and their significance for our lives together in communities, such as Carrie Noland's Agency and Embodiment and Manning's own Politics of Touch, and perhaps most significantly Jane Bennett's Vibrant Matter and Diana Coole and Samantha Frost's New Materialisms, we are now presented with this book which strives to explore creative practices as a form of thinking.

Its underlying goal is a very ambitious one, to 'open philosophy to the outside' as it argues that 'every practice is a mode of thought, already in the act.' (vii). Its mission then is not to philosophize about artistic action as the underlying argument is that artistic action is in and of itself already a form of thought. Thus the aim becomes significant both in method and in argument; the authors do not analyse practices; they try to understand them from within, to unravel their logic and unfold their intricacies. This book focuses on creating a relational ecology in more than one way. It, in its own unique mode of writing, allows the reader to partake in one such ecology, in a mode of being in which different discourses can live together without the need to prioritize one over the other; a life in which rationality or understanding take manifold meanings, and difference, in the deepest meaning of the phrase, is celebrated.

The book is divided into two parts: the first, Passages, provides readings of practices. The first chapter entitled neurodiversity is a reading of the experience of perception, focusing on the experience of perception of autistic people, as opposed to neuroreductionism. Massumi and Manning want us to return to the experience of a whole moment bringing the experience of perception back into relational terms. The next chapter looks at a possible dialogue between mathematician and philosopher Alfred North Whitehead and the work of architects and artists Arkawa and Gins. We have a verbal travel through the experience of receiving their work, experiencing their re-configuration of spaces and intervention into the physicality of our lives. The next two chapters are devoted to readings of two artists: influential

(C) 2015 Macmillan Publishers Ltd. 1470-8914 Contemporary Political Theory Vol. 14, 4, e22-e24 www.palgrave-journals.com/cpt/ 
choreographer William Forsythe (in a work inspired by Virginia Woolf's Mrs Dalloway) and photographer Bracha Ettinger. Then we move into the second part of the book, Propositions. This part of the book is written as an exploration into SenseLab, a laboratory for thought in motion founded by Erin Manning herself in 2004. This part of the book explores both the logic behind it, the experiences of participants in it as well as its final disintegration. This final section allows the reader to take different perspectives of different people involved in SenseLab.

The call to return relationality into the language of political theory is most welcome and needed. Following works cited above we know that the living, breathing human body never exists in a social vacuum and always relates to other bodies. Thus, it can form what Manning and Massumi call an ecology. We live among a network of physical entities, human and non- human, which exist only in relation to each other. The book is unique in its magnificent use of form in aid of content; the reader experiences this rationality as they are thrown into a whirlwind of sensory experiences while reading the book. This is not merely a philosophical experience of a diverse set of practices; the reader undergoes, while reading, the unravelling of experiencing practice as philosophy. With phrases such as, while discussing Ettinger's work 'the emergent figural field- effects become less formed, more vibratory' (p. 76) or, in the proposition chapter, discussing creative processes underwent by participants of SenseLab, 'attention flags. Bodies fatigue. Stomachs growl' (p. 100); the reader does not only read about a new way to practice philosophy they experience it through their bodies and minds. The act of reading in itself becomes a sensed experience.

The one question arising out of this book is the conceptual relationship between relationality and intentionality. The book strives to open philosophy to discourses which do not always exist as part of it, and moreover to show that without intending to, those discourses generate a philosophical form of life of its own. The aim is to steer away from paternalism and from hierarchies which see one form of discourse as superior to the other. At the same time, the book gives a large space to authorial intention: whether it is by using multiple quotes from William Forsythe in the chapter discussing his work or by focusing on SenseLab, Manning's own enterprise. Can we, indeed, intervene in the idea of philosophy, or political theory, asking to talk about 'event formation' (p. vii) while detaching this process from the author's intention? It seems not. Moreover, we are told, that 'the SenseLab does not exist "as such". It is not an organization' (p. 151). In the aim to celebrate difference and spontaneous sensed experience there is a meta-organization that guides those contributing to this experience as well as us as the readers, recipients of this experience. The aim to insert diversity into hierarchies in philosophy necessitates creating new structures which embody power relations, in theory and practice, both. At the same time, one can probe further and ask, wlhat do we learn about other modes of being and thinking from the relationship between intent and being together in the SenseLab, then? Many questions remain unanswered. The relationship between the method of the book and 
its stated goals show us a much more complex image of the idea of 'event formation' than can be derived from the chapters themselves and the underlying conceptual structure. Every chapter works powerfully as a stand-alone piece, but thinking of a relationally constructed structure in which diversity is celebrated may be more difficult than can be read in each case study. Trying to transcend difference in practices and their techniques, it seems, cannot be detached from the actual effort itself, from the explicit goal to overcome discursive, disciplinary and intellectual boundaries.

The power of this book lies in its unique ability to throw the reader into an aesthetic experience of philosophy. Thus the book is a significant intrusion in form and content alike. This book is a powerful intervention into philosophy as a discipline, and an important contribution to work focusing on the sensed experience and its relationship to our ways of being and living together.

Dana Mills

Hertford College, University of Oxford, Oxford OX1 3BW, UK dana.mills@hertford.ox.ac.uk 